\title{
Manajemen Anestesi pada Seksio Sesarea Pasien dengan HIV (Human Immunodeficiency Virus)
}

\author{
Iwan Nuryawan', Bambang Suryono², Sri Rahardjo² \\ ${ }^{1}$ Peserta didik Subspesialis Minat Anestesi Obstetri Anestesiologi dan Terapi Intensif Fakultas Kedokteran \\ Kesehatan Masyarakat dan Keperawatan Universitas Gajah Mada/RSUP Dr Sardjito Yogyakarta, ${ }^{2}$ Konsultan \\ Anestesi Obstetri Departemen Anestesiologi dan Terapi Intensif Fakultas Kedokteran Kesehatan Masyarakat dan \\ Keperawatan Universitas Gajah Mada-RSUP Dr Sardjito Yogyakarta²
}

\begin{abstract}
Abstrak
Infeksi Human Immunodeficiency Virus (HIV) dan Acquired Immunodeficiency Syndrome (AIDS) adalah masalah utama dari kesehatan global. Menurut United Nations Programme on HIV/AIDS (UNAIDS), salah satu bagian dari WHO yang mengurus tentang AIDS menyebutkan, bahwa perkiraan jumlah penderita yang terinfeksi HIV/ AIDS di seluruh dunia sampai dengan akhir tahun 2010 mencapai 34 juta. Kasus HIV pada anak paling sering ditemukan akibat transmisi dari ibu yang HIV positif ke anaknya. Pada laporan kasus ini dilaporkan penanganan anestesi pada penderita pasien wanita berusia 25 tahun berat badan $50 \mathrm{~kg}$ primigravida hamil aterm $38 \mathrm{minggu}$ belum dalam persalinan dengan infeksi HIV belum mendapatkan terapi antiretroviral. Pasien diklasifikasikan ASA II dan dilakukan anestesi regional teknik blok subarakhnoid dengan obat bupivakin 0,5\% hiperbarik $10 \mathrm{mg}$. Dilahirkan bayi perempuan berat lahir 2500 gram, dengan skor Apgar 9/10. Operasi berlangsung selama 1 jam dengan hemodinamik TD 90-120/60-80 mmHg, HR 65-100 x/mnt, SpO 299-100\%, perdarahan 400 cc, produksi urin $0,5 \mathrm{ml} / \mathrm{kgBB} / \mathrm{jam}$. Pasca operasi pasien diobservasi di ruang pemulihan hingga skor Bromage 0 sebelum dikembalikan ke bangsal.
\end{abstract}

Kata kunci: anestesi; seksio sesarea; infeksi HIV; terapi antiretroviral

\section{Anesthesia Management in Cesarean Section Patients with HIV (Human Immunodeficiency Virus)}

\begin{abstract}
Human Immunodeficiency Virus (HIV) and Acquired Immunodeficiency Syndrome (AIDS) infections are the main problems of global health. According to United Nations Programme on HIV/AIDS (UNAIDS), one part of the WHO that deals with AIDS states that the estimated number of people infected with HIV/AIDS worldwide by the end of 2010 reached 34 million. HIV cases in children are most often found due to the transmission of HIV-positive mothers to their children. We reported a 25 -year-old primigravida, 38 weeks, weighing $50 \mathrm{~kg}$, not in delivery with HIV infection without antiretroviral therapy underwent caesarean section. Patient was classified as ASA II and performed subarachnoid blocks with hyperbaric $0.5 \mathrm{mg}$ bupivacaine $10 \mathrm{mg}$. A baby girl was born, weighing 2500 grams, with Apgar score 9/10. The operation lasts for 1 hour with hemodynamics TD 90-120/60-80 $\mathrm{mmHg}$, HR 65-100 x/min, $\mathrm{SpO}_{2} 99-100 \%$, bleeding $400 \mathrm{cc}$, urine production $0.5 \mathrm{ml} / \mathrm{kgBW} /$ hour. In postoperative period, patient was observed in the recovery room until the Bromage score was 0 before transferred to the ward.
\end{abstract}

Key words: cesarean section; HIV infection; antiretroviral therapy; anesthesia 


\section{Pendahuluan}

Infeksi Human Immunodeficiency Virus (HIV) dan Acquired Immunodeficiency Syndrome (AIDS) adalah masalah utama dari kesehatan global. Menurut United Nations Programme on HIV/ AIDS (UNAIDS), salah satu bagian dari WHO yang mengurus tentang AIDS menyebutkan bahwa perkiraan jumlah penderita yang terinfeksi HIV/ AIDS di seluruh dunia sampai dengan akhir tahun 2010 mencapai 34 juta. ${ }^{1}$ Tahun 2003 diperkirakan 700.000 bayi baru lahir terinfeksi HIV2. Laporan CDC (Central for Disease Control) Amerika memaparkan bahwa seroprevalensi HIV pada ibu prenatal adalah $0,0 \%-1,7 \%$, pada saat persalinan $0,4 \%-2,3 \%$ dan $9,4-29,6 \%$ pada ibu hamil yang biasa menggunakan narkotika intravena. ${ }^{3}$ Kasus HIV pada anak paling sering ditemukan akibat transmisi dari ibu yang HIV positif ke anaknya. Lebih dari 90\% penularan HIV dari ibu ke anak terjadi selama dalam kandungan, persalinan dan menyusui. ${ }^{2,4}$

Angka morbiditas dan mortalitas yang disebabkan oleh HIV semakin meningkat dan merupakan masalah kesehatan masyarakat yang paling penting di seluruh dunia. Hingga sampai saat ini belum ditemukan imunisasi profilaksis atau pengobatan AIDS, meskipun demikian terapi antiretrovirus seperti Highly Active Antiretroviral Therapy (HAART) tetap dikembangkan. Penggunaan obat antivirus dan persalinan berencana dengan seksio sesarea telah menurunkan angka transmisi perinatal penyakit ini dari 30\% menjadi 20\%.5 Sekitar 20 sampai $25 \%$ pasien HIV positif memerlukan tindakan seksio sesarea. Dokter anestesiologi harus memperhatikan penyakit tersebut untuk menentukan pilihan anestesi. Penyakit multiorgan ini dapat berkomplikasi baik berupa infeksi oportunistik, tumor, penyalahgunaan obat, atau terapi obat antiretroviral yang semuanya dapat berimplikasi terhadap tindakan anestesi. ${ }^{6}$

\section{Kasus}

Pasien wanita umur 25 tahun, kehamilan ketiga, usia kehamilan 38 minggu, dengan HIV belum dalam persalinan. Pasien dikonsulkan untuk rencana seksio sesarea elektif. Anamnesa, pasien didiagnosa didiagnosis HIV sejak 4 bulan sebelum masuk RS dan tidak mendapatkan terapi. Pasien mempunyai kebiasaan merokok dan minum minuman keras. Pada lengan kanan didapatkan gambar tato sejak 3 tahun lalu.

Pada pemeriksaan fisik didapatkan: (1) keadaan umum baik, kompos mentis; (2) tanda vital; tekanan darah 120/80 $\mathrm{mmHg}$, nadi $84 \mathrm{x} /$ menit, laju napas $18 \mathrm{x} / \mathrm{menit}$, suhu $36,0^{\circ} \mathrm{C}$; (3) jalan napas bebas, tidak ada pembengkakan, gerakan leher bebas; (4) jantung dan paru tidak didapatkan kelainan; (5) abdomen, tinggi fundus uteri 2 jari di bawah processus xyphoideus, (6) ekstremitas akral hangat, tanpa edem tungkai.

Pada pemeriksaan penunjang didapatkan: $\mathrm{Hb}$ $10.3 \mathrm{gr} / \mathrm{dL}$, HMT $31.1 \%$, Na $142 \mathrm{mmol} / \mathrm{L}, \mathrm{K}$ $3.8 \mathrm{mEq} / \mathrm{L}$, AL 7,2000/mm3, limfosit $14,7 \%$, AT 291,000/mm3, AE 4,100,000 mm3, Cl 104 $\mathrm{mEq} / \mathrm{L}$, GDS $71 \mathrm{mg} / \mathrm{dL}$, Alb $3.92 \mathrm{mg} / \mathrm{dL}$, SGOT/ PT 36/34 U/I, Ureum/kreatinin 13/0.62 mg/ dL, PT/APTT 8,0/29,5 detik. Imuno serologi : HIV DUO Ultra (VIDAS ): $18,15 \mathrm{Neg}<0,25$, Hematologi CD4: D4 Absolut 205,6 sel/ul, CD4 \% 21,2 \% CD8: CD8 Absolut 521,8 sel/ul CD8 \% 53,89 \%, Rasio CD4: CD8 0,39. Kesan: limfosit $\mathrm{T}$ helper rendah dan $\mathrm{T}$ supressor normal dengan rasio $\mathrm{CD} 4$ : $\mathrm{CD} 8$ rendah.

Pasien dinilai sebagai status fisikASAII. Persiapan di ruang rawat inap meliputi informed consent dan puasa 8 jam pra operasi. Di kamar operasi dipasang jalur intravena dengan jarum nomer 18 dengan cairan kristaloid RL. Pemantauan hemodinamik non invasif dengan EKG, pulse oksimetri dan tekanan darah. Dilakukan anestesi regional dengan teknik blok subarakhnoid, pasien diposisikan duduk, puncture di VL 3-4 proyeksi median dengan jarum spinal 25 gauge dengan obat anestesi lokal bupivakain 0,5\% hiperbarik $10 \mathrm{mg}$. Standar keamanan universal precaution, dokter anestesi menggunakan apron plastik, masker, sarung tangan steril, kaca mata goggle, alas kaki sepatu, serta disediakan box khusus untuk membuang benda tajam seperti jarum, ampul obat dan sampah medis. Dilahirkan bayi perempuan berat lahir 2500 
dari sel hospes. Bentuk DNA integrasi dari HIV disebut provirus, yang mampu bertahan dalam bentuk inaktif selama beberapa bulan atau beberapa tahun tanpa memproduksi virion baru. ${ }^{11}$

Monitoring Durante Operasi

\begin{tabular}{llll}
\hline $\begin{array}{l}\text { Waktu/ } \\
\text { Jam }\end{array}$ & $\begin{array}{l}\text { Tekanan } \\
\text { Darah }\end{array}$ & $\begin{array}{l}\text { Heart } \\
\text { Rate }\end{array}$ & Saturasi \\
\hline 14.15 & $98 / 50$ & 107 & 100 \\
14.18 & $93 / 47$ & 65 & 100 \\
14.20 & $108 / 52$ & 78 & 100 \\
14.23 & $111 / 55$ & 76 & 100 \\
14.25 & $112 / 59$ & 80 & 100 \\
14.27 & $116 / 66$ & 88 & 100 \\
15.00 & $114 / 64$ & 84 & 100 \\
\hline
\end{tabular}

gram, dengan skor Apgar 9/10. Setelah bayi lahir, diberikan oksitosin 10 IU intravena sebagai uterotonika. Operasi berlangsung selama 1 jam dengan perdarahan $400 \mathrm{cc}$, produksi urin 0,5 $\mathrm{cc} / \mathrm{kgBB} / \mathrm{jam}$. Pasca operasi pasien diobservasi di ruang pemulihan hingga skor Bromage 0 sebelum dikembalikan ke bangsal. Kehamilan ini merupakan kehamilan ketiga bagi pasien dan saat hamil ini pasien berusia 25 tahun. Pasien sebelumnya didiagnosis dengan HIV 4 bulan sebelum masuk kamar bersalin dan tidak mendapatkan obat obatan. Usia kehamilan pasien adalah 38-39 minggu, maka penanganan pada pasien setelah dirawat di ruangan pasien disiapkan untuk dilakukan tindakan terminasi secara pervaginam, untuk mengurangi transmisi secara vertikal (perinatal). Persalinan dengan seksio sesarea secara berencana sebelum saat persalinan tiba merupakan pilihan utama pada orang dengan HIV-AIDS (ODHA). Pada saat persalinan pervaginam, bayi terpapar darah dan lendir ibu di jalan lahir. Bayi mungkin juga terinfeksi karena menelan darah atau melalui lendir jalan lahir tersebut. Beberapa hasil penelitian menyimpulkan bahwa seksio sesarea akan mengurangi risiko penularan HIV dari Ibu ke bayi sebesar $50-60 \%$.).

Pasien ini belum mendapatkan terapi ARV. Berdasarkan kepustakaan, pada pasien ODHA tanpa pemberian ARV, $25 \%$ bayi dengan ibu HIV positif akan tertular sebelum dilahirkan atau pada waktu lahir, dan $15 \%$ tertular melalui ASI. Pada ODHA dewasa, penentuan saat yang tepat memulai terapi obat antiretroviral (ART) selain dengan menggunakan stadium klinis, diperlukan pemeriksaan CD4. Pemberian ART pada ibu hamil HIV positif selain dapat mengurangi risiko penularan HIV dari ibu ke anak, adalah untuk mengoptimalkan kondisi kesehatan ibu dengan cara menurunkan kadar HIV serendah mungkin. Pemberian ART sebaiknya disesuaikan dengan kondisi klinis yang sedang dialami oleh ibu.

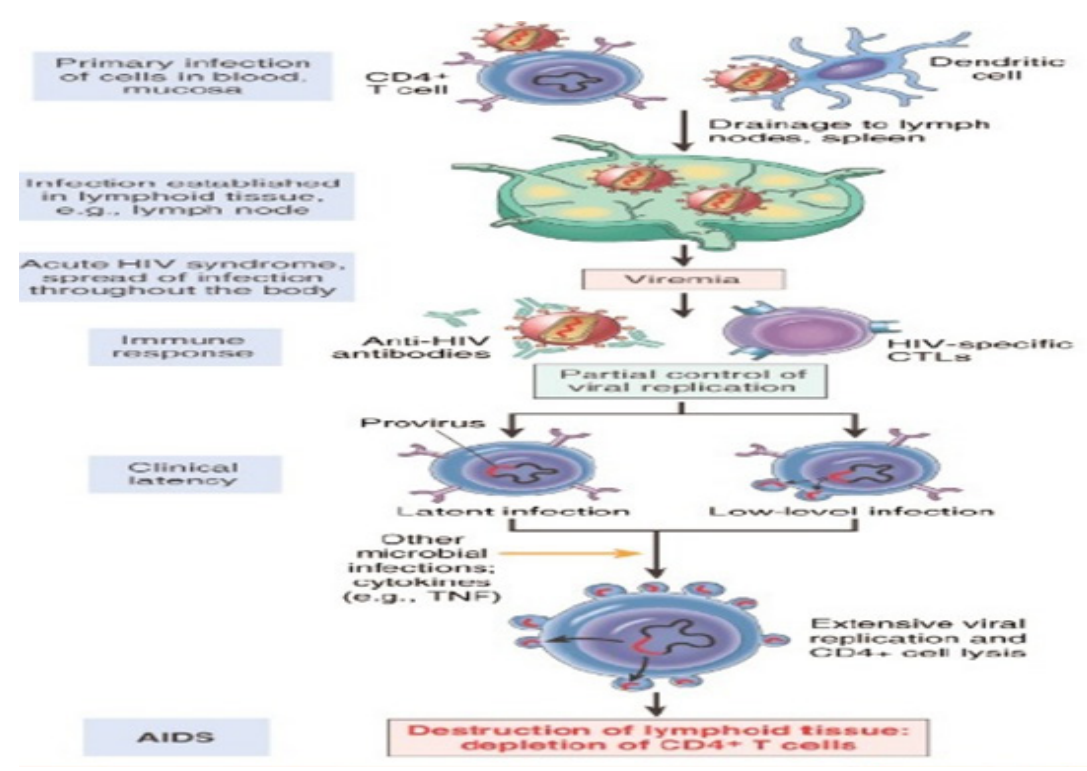

Gambar 1. Patofisiologi HIV 
Tabel 1. Diagnosis Klinis Infeksi HIV pada Orang Dewasa (WHO)

\begin{tabular}{|c|c|c|}
\hline Stadium & Gambaran Klinis & Skala Aktivitas \\
\hline I & $\begin{array}{ll}\text { - } & \text { Asimptomatik } \\
\text { - } & \text { Limfadenopti generalisata }\end{array}$ & Asimptomatik, aktivitas normal \\
\hline II & $\begin{array}{l}\text { - } \quad \text { Berat badan menurun }<10 \% \\
\text { Kelainan kulit dan mukosa yang ringan } \\
\text { seperti dermatitis seboroik, prurigo, oni- } \\
\text { komikosis, ulkus oral yang rekuren, khilitis } \\
\text { angularis } \\
\text { - } \quad \text { Herpes zoster dalam } 5 \text { tahun terakhir } \\
\text { - ISPA seperti sinusitis bakterialis }\end{array}$ & Simptomatik, aktivitas normal \\
\hline III & $\begin{array}{ll}\text { - } & \text { Berat badan menurun }>10 \% \\
\text { - } & \text { Diare kronis }>1 \text { bulan } \\
\text { - } & \text { Kanam berkepanjangan }>1 \text { bulan } \\
\text { - } & \text { Oral hairy leukoplakia } \\
\text { - } & \text { TB paru dalam tahun terakhir } \\
\text { - Infeksi bakterial berat seperti pneumonia, } \\
\text { piomiositis }\end{array}$ & $\begin{array}{l}\text { Pada umumnya lemah, aktivitas di tempat } \\
\text { tidur }<50 \%\end{array}$ \\
\hline IV & $\begin{array}{ll}\text { - } & \text { HIV wasting syndrome seperti yang } \\
\text { - } & \text { didefinisikan CDC } \\
\text { - } & \text { Toksopononia Pneumocytis carinii } \\
\text { - } & \text { Diare kriptoporidiosis }>1 \text { bulan } \\
\text { - } & \text { Kriptokokosis ekstrapulmonal } \\
\text { - } & \text { Retinitis virus cytomegalo } \\
\text { - } & \text { Herpes simpleks mukokutan }>1 \text { bulan } \\
\text { - } & \text { Leukoensepalopati multifokal progresif } \\
\text { - } & \text { Mikosis diseminata seperti histoplasmosis } \\
\text { - } & \text { Kandidiasis di esofagus, trakea, bronkus, } \\
\text { - } & \text { dan paru } \\
\text { - } & \text { Septikobakteriosis atipikal diseminata } \\
\text { - } & \text { Tuberkulosis di luar paru } \\
\text { - } & \text { Limfoma } \\
\text { - } & \text { Sarkoma kaposi } \\
\text { - } & \text { Ensefalopati HIV }\end{array}$ & $\begin{array}{l}\text { Pada umumnya sangat lemah, aktivitas di } \\
\text { tempat tidur }>50 \%\end{array}$ \\
\hline
\end{tabular}

aktivasi poliklonal B sel akibat pengaruh HIV. Perusakan sel B, mengakibatkan pembentukan antibodi sekunder lemah, dan respons terhadap vaksinasi buruk. Defek sel mediated juga terjadi, sehingga mudah terjadi infeksi oportunis seperti jamur Pneumocystis jiroveci yang menyebabkan pneumocystis carinii pneumonia (PCP) dan diare kronik. ${ }^{2,10}$ HIV menggunakan CD4 untuk masuk ke dalam host sel $\mathrm{T}$ dengan cara mengikat gp120 pada CD4. Keterikatan menciptakan pergeseran dalam konformasi gp120 HIV yang memungkinkan untuk mengikat ke co-reseptor untuk diekspresikan pada sel inang. HIV menyisipkan peptida fusi ke dalam sel host yang memungkinkan membran luar virus untuk berfusi dengan membran sel. ${ }^{11}$ Sekali virion HIV masuk ke dalam sel, maka enzim yang terdapat dalam nukleoprotein menjadi aktif dan memulai siklus reproduksi virus. Nukleoprotein inti virus menjadi rusak dan genom RNA virus akan ditranskripsi menjadi DNA untai ganda oleh enzim reverse transcriptase dan kemudian masuk ke nukleus. Enzim integrase akan mengkatalisa integrasi antara DNA virus dengan DNA genom 
Table 2. Terapi Antiretroviral1 ${ }^{5}$

\begin{tabular}{|c|c|c|}
\hline No & Situasi Klinis & Rekomendasi Pengobatan \\
\hline 1 & $\begin{array}{l}\text { ODHA sedang terapi ARV, kemudian } \\
\text { hamil }\end{array}$ & $\begin{array}{l}\text { Lanjutkan panduan (ganti dengan NVP atau golonga } \\
\text { PI jika sedang menggunakan EVF pada trimester II) } \\
\text { Lanjutkan dengan paduan ARV yang sama selama } \\
\text { dan sesudah persalinan }\end{array}$ \\
\hline 2 & $\begin{array}{l}\text { ODHA hamil dengan jumlah dalam } \\
\text { stadium klinis } 1 \text { atau jumlah CD } 4 \\
>350 / \mathrm{mm} 3 \text { dan belum terapi ARV }\end{array}$ & 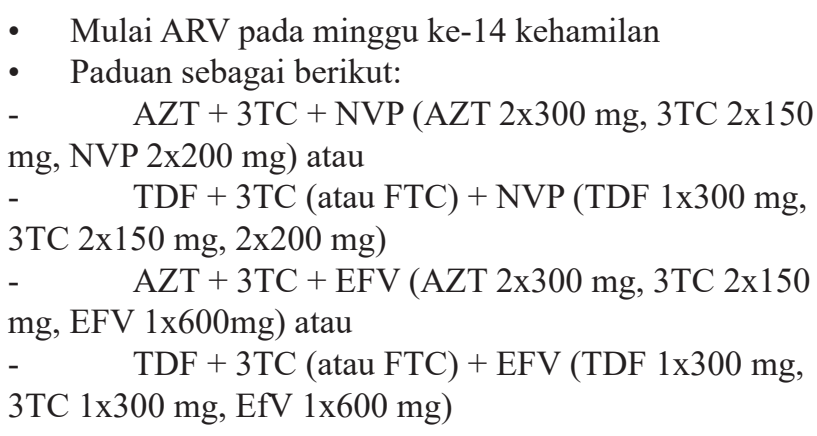 \\
\hline 3 & $\begin{array}{l}\text { ODHA hamil dengan jumlah CD4 } \\
<350 / \mathrm{mm} 3 \text { atau stadium klinis } 2,3,4\end{array}$ & $\begin{array}{l}\text { Segera mulai terapi ARV dengan paduan seperti pada } \\
\text { butir }\end{array}$ \\
\hline 4 & $\begin{array}{l}\text { ODHA hamil dengan tuberculosis } \\
\text { aktif }\end{array}$ & $\begin{array}{l}\text { - } \quad \text { OAT tetap diberikan } \\
\text { Paduan untuk ibu, bila pengobatan mulai trimester II } \\
\text { dan III: AZT (TDF) }+3 \mathrm{TC}+\mathrm{EFV}\end{array}$ \\
\hline 5 & $\begin{array}{l}\text { Ibu hamil dalam masa persalinan dan } \\
\text { status HIV tidak diketahui }\end{array}$ & $\begin{array}{l}\text { Tawarkan tes HIV dalam masa persalinan atau tes } \\
\text { setelah persalinan. Jika hasil tes reaktif, dapat diberi- } \\
\text { kan paduan pada butir } 2\end{array}$ \\
\hline 6 & $\begin{array}{l}\text { ODHA datang pada masa persalinan } \\
\text { dan belum mendapat terapi ARV }\end{array}$ & Lihat paduan butir 2 \\
\hline
\end{tabular}

\section{Pembahasan}

Human Immunodeficiency Virus (HIV) adalah sejenis virus yang menyerang kekebalan tubuh manusia dan dapat menimbulkan AIDS (Acquired Immunodeficiency Syndrome). Salah satu jenis sel-sel darah putih yang bertugas menangkal infeksi, sel darah putih tersebut terutama limfosit yang memiliki CD4, sebagai penanda yang berada di permukaan sel limfosit. Pada orang dengan sistem kekebalan yang baik, nilai CD4 berkisar antara 1400-1500. Pada orang dengan sistem kekebalan yang terganggu (misal pada orang yang terinfeksi HIV) nilai CD4 semakin lama akan semakin menurun. ${ }^{2} \mathrm{HIV}$ adalah jenis parasit obligat yaitu virus yang hanya dapat hidup dalam sel atau media hidup. Seorang pengidap HIV lambat laun akan jatuh ke dalam kondisi AIDS, apalagi tanpa pengobatan. Umumnya keadaan AIDS ini ditandai dengan adanya berbagai infeksi baik akibat virus, bakteri, parasit maupun jamur. Keadaan infeksi ini yang dikenal dengan infeksi oportunistik. ${ }^{7}$ Kasus AIDS pertama kali dilaporkan di Indonesia pada tahun 1987 pada seorang WNA di Bali. Sampai 31 Desember 2011, kasus HIV dan AIDS yang dilaporkan sejak 1987 berjumlah masing-masingnya 76.879 dan 29.879 kasus, dengan angka kematian 5.430 kasus. Infeksi HIV terutama berpengaruh pada sel CD4 dan sel monosit atau sel makrofag. Setelah sel terkena infeksi, maka RNA virus sampul terlepas, dan membentuk DNA transkrip rangkap dua, yang ditransfer ke sel DNA host, dan terjadilah perusakan sistem imunologi baik humoral ataupun selular. Kemudian bersama dengan sitokin yang dipengaruhi akan mempengaruhi fungsi makrofag, B limfosit dan $\mathrm{T}$ limfosit. Hipergamaglobulinemia yang terdeteksi pada saat kehamilan, disebabkan 
Virion terikat dengan dengan bagian luar sel dan bergabung dengan sel kemudian protein inti dan dua benang RNA virus masuk ke sel. DNA doublestranded termigrasi ke inti sel melepas sampulnya berintegrasi dengan DNA sel. Provirus selanjutnya menjadi laten. Proses dapat berlangsung perlahan atau secara cepat sehingga terjadi lisis atau ruptur dari sel. ${ }^{10}$ Setiap stadium penyakit dilandaskan pada hitung CD4 darah perifer dan manifestasi klinik. Hitung CD4 dibagi tiga kriteria, normal $(>500 / \mathrm{mm} 3)$ sampai deplesi berat $(<200 / \mathrm{mm} 3)$. Kategori HIV A. terdiri manifestasi minimal, tidak memperlihatkan turunnya imun, limfadenopati umum. Kategori B. terdiri kondisi defek imunitas seluler atau infeksi HIV yang memburuk. Kategori C. terdiri kondisi AIDS dan hitung sel CD4 $<200 / \mathrm{mm} 3 .{ }^{13}$

Kasus HIV pada anak biasanya paling sering ditemukan akibat transmisi dari ibu yang sudah memiliki HIV ke anaknya. Kemungkinan besar perpindahan virus ini terjadi selama proses kehamilan dan juga persalinan maupun menyusui. ${ }^{2}$ Transmisi HIV dari ibu ke anak tersebut timbul mendekati $25-30 \%$ dari bayi yang lahir dari ibu yang tidak mendapat pengobatan anti virus selama kehamilan, sedangkan waktu terjadinya infeksi vertikal dari HIV belum dapat ditentukan dengan baik. Transmisi intra uterin telah ditunjukkan secara langsung dengan deteksi virus pada jaringan abortus fetal. Kebanyakan episode dari infeksi kongenital HIV timbul selama periode intrapartum, mungkin berhubungan dengan terpaparnya bayi terhadap darah ibu yang terinfeksi dan sekret serviks atau vagina. penularan postnatal adalah melalui air susu ibu..$^{9,10}$

Identifikasi pasien hamil dengan HIV/AIDS penting untuk ahli anestesiologi. Diagnosis infeksi HIV dapat dikonfirmasi melalui kultur virus langsung dari limfosit dan monosit darah tepi. Diagnosis juga dapat ditentukan oleh deteksi antigen virus dengan polymerase chain reaction (PCR). Terlihat penurunan jumlah $\mathrm{CD} 4$, ratio $\mathrm{CD} 4$ dan $\mathrm{CD} 8$ terbalik dan level serum imunoglobulin meningkat pada HIV positif. Enzyme-linked immunosorbent assay (ELISA) merupakan tes skrining HIV yang paling sering digunakan unruk mengidentifikasi antibodi spesifik virus, baik tipe HIV-1 maupun HIV-2.

Tes ini harus dikonfirmasi dengan Western blot assay atau immunoflourescent antibody assay (IFA), untuk mendeteksi antigen spesifik virus. ${ }^{14}$ American Congress of Obstetrics and Gynecology (ACOG) merekomendasikan wanita berumur 1964 tahun untuk melakukan skrining HIV secara rutin, khususnya wanita yang beresiko tinggi diluar umur tersebut. Pada kunjungan prenatal pertama, ibu hamil harus melakukan skrining untuk infeksi HIV. Apabila ibu menolak untuk melakukan tes, hal tersebut harus dicantumkan kedalam rekam medisnya dan skrining bisa dilakukan lagi sebelum umur kehamilan 28 minggu. Apabila hasil tes negatif tetapi dokter memutuskan bahwa ibu adalah resiko tinggi terinfeksi HIV, tes bisa diulang kembali pada trimester ketiga. ${ }^{15}$ Wanita yang sedang pengobatan Highly active antiretroviral therapy (HAART) harus dilakukan monitoring terhadap intoksikasi obat seperti jumlah sel darah, ureum, elektrolit, fungsi hepar, laktat, dan gula darah. Adanya gejala dan tanda preeklamsi, kolelitiasis, atau gangguan fungsi hati selama kehamilan menandakan adanya intoksikasi obat. ${ }^{16}$

Monitoring janin intensif termasuk adanya gangguan anatomi, gangguan pertumbuhan, dan fetal well being pada saat trimester III diharuskan pada ibu hamil yang mendapat obat kombinasi HAART untuk melihat efek obat pada janin. ${ }^{16}$ Obat-obatan Antiretroviral (ARV) bukanlah suatu pengobatan untuk HIV/AIDS tetapi cukup memperpanjang hidup dari mereka yang mengidap HIV. Pada tempat yang kurang baik pengaturannya permulaan dari pengobatan ARV biasanya secara medis direkomendasikan ketika jumlah sel CD4 dari orang yang mengidap HIV/AIDS adalah 200 atau lebih rendah. ${ }^{17}$ Seorang wanita yang mengidap $\operatorname{HIV}(+)$ dapat menularkan HIV kepada bayinya selama masa kehamilan, persalinan dan masa menyusui. Berikan antiretroviral segera kepada semua ibu hamil dengan HIV, tanpa harus mengetahui nilai CD4 dan stadium klinisnya terlebih dahulu, dan dilanjutkan seumur hidup. Rekomendasi pengobatan sesuai situasi klinis ibu dapat dilihat 
di tabel 2. Obat-obat anestesi dapat berinteraksi dengan obat-obatan ARV. Agen anestesi dapat meningkatkan perubahan farmakodinamik yang berefek pada efikasi dan toksitas obat- obat ARV, dan efek farmakokinetik obat-obat ARV dapat berefek pada absorpsi, distribusi, metabolisme dan eliminasi obat-obat anestesi. ${ }^{18}$ Interaksi farmakodinamik dapat diatur dengan mencegah penggunaan agen anestetik seperti halothane atau methoxyflurane yang dapat menyebabkan disfungsi hepar atau renal. Propofol dan NRTI abacavir, didanosine, emtricitabine, lamivudine, stavudine, dan zidovudine dapat menyebabkan toksitas mitokondrial dan asidosis laktat. ${ }^{6,18}$ Interaksi farmakokinetik sangat kompleks dan secara primer disebabkan oleh inhibisi atau induksi enzym liver, khususnya CYP450 dan 3A4 enzyme. Protease inhibitors (PIs) dan NNRTI adalah kelompok obat ARV yang paling banyak berinteraksi dengan obat- obatan anestesi. Perubahan fisiologis kehamilan mempengaruhi farmakokinetik obat antiretroviral meliputi peningkatan volum plasma, curah jantung, laju filtrasi glomerulus, penurunan protein plasma untuk mengikat obat, dan perubahan di tingkat enzim. Induksi atau inhibisi enzym liver tersebut dapat mempengaruhi aktivitas dari obat-obatan anestesi ${ }^{6}$ :

- Opioid. Efek fentanyl fentanil dapat dipengaruhi oleh ritonavir akibat inhibisi dan induksi enzym liver. Inhibisi enzyme enzim menurunkan waktu clearence fentanil dan induksi enzim meningkatkan metabolisme menuju aktif metabolit seperti normeperidin.

- Benzodiazepin. Saquinavir dapat menghambat metabolisme midazolam.

- Calcium channel blockers dapat mempengaruhi efek hipotensi akibat inhibisi enzim.

- Anestetika lokal seperti lignokain dapat meningkatkan level kadar plasma akibat inhibisi enzim.

- Efek neuromuscular blocker dapat memanjang, sehingga digunakan dosis tunggal vekuronium untuk instance.

Seksio sesarea elektif pada kasus pasien hamil dengan HIV/AIDS merupakan pilihan. untuk mengurangi angka kejadian transmisi HIV dari ibu ke bayi. Pasien yang menjalani terapi antiretroviral dan direncanakan seksio sesarea elektif dapat mengurangi angka kejadian transmisi vertikal sampai $<5 \%$. Pada pasien hamil dengan HIV/AIDS diperlukan pemeriksaan preoperatif untuk: (a) menilai kondisi fisik, terapi, dan infeksi oportunistik yang ada; (b) merencanakan teknik anestesi yang aman; (c) menilai terapi dan implikasi bagi tindakan anestesi; (d) memprediksikan prognosis. ${ }^{19}$

Pada pasien ini tidak dikeluhkan adanya efek samping seperti anemia, gangguan pencernaan, gatal, ataupun parese. Pada pemeriksaan fisik, tidak didapatkan konjungtiva anemis, tidak ada skin rash, tidak ada edema tungkai, dan fungsi neurologis dalam batas normal. Berdasarkan gambaran di atas, maka pasien tergolong sudah ada simtom diantaranya hematologi yaitu turunnya angka limfosit sehingga dinilai status fisik dengan ASA II. Infeksi HIV berpengaruh pada hasil kehamilan diantaranya berat lahir rendah (kurang dari 2500 gram), kecil masa kehamilan, dan dengan nilai Apgar yang rendah. Infeksi HIV juga meningkatkan risiko terjadinya persalinan prematur dan komplikasi toksoplasmosis SSP $30 \%$ lebih besar pada pasien dengan hitung CD4 kurang dari $300 \mathrm{sel} / \mathrm{mm} 3 .{ }^{20}$

Langkah pertama penatalaksanaan anestesi pada pasien HIV/AIDS adalah review status penyakit pasien dan terapi yang digunakan. Pemeriksaan meliputi pengobatan terakhir yang digunakan pasien, dan evaluasi laboratorium hitung CD4. Pasien dengan hitung CD4 tinggi $(>500-700 / \mathrm{mm} 3)$ biasanya tidak disertai infeksi oportunistik. Sebaliknya, pada pasien dengan infeksi oportunistik (hitung CD4 $<200 / \mathrm{mm} 3$ ) diperlukan pemeriksaan laboratorium lainnya meliputi darah rutin, masa perdarahan, masa pembekuan, fungsi hati, fungsi ginjal, viral load, EKG, radiografi toraks, dan ekokardiografi. Ketika dipertimbangkan untuk anestesi umum pada populasi ini, adanya penyakit jantung dan paru harus menjadi perhatian. Teknik anestesi untuk operasi pada pasien dengan HIV/AIDS dipilih berdasarkan penilaian preoperatif. Teknik anestesi regional digunakan apabila tidak ada gangguan koagulopati dan tidak ada gangguan 
neurologis sedangkan apabila dipilih teknik anestesi umum maka obat-obat yang digunakan dapat berinteraksi dengan obat antiretroviral golongan protease inhibitor sehingga dapat mempengaruhi metabolismenya. ${ }^{6}$

Pada kasus ini dipilih tehnik anestesi spinal karena tidak didapatkan gangguan koagulopati dan gangguan neurologis. Larutan anestesi lokal untuk anestesi spinal pada pasien obstetri lebih dipilih hiperbarik. Agen hiperbarik menghasilkan onset blok lebih cepat dan ketinggian blok sensorik maksimal yang diharapkan. Teknik anestesi neuraksial aman digunakan pada pasien dengan HIV yang menjalani bedah sesar dan tidak memicu progresivitas penyakit terhadap sistem saraf pusat. Pemeriksaan fisik dan dokumentasi defisit neurologis yang baik harus dilakukan sebelum dilakukan induksi anestesi regional. ${ }^{20}$ Terapi untuk komplikasi anestesi neuraksial, meliputi tatalaksana postdural puncture headache tidak berbeda dengan pasien dengan HIV negatif. Khususnya, bila terjadi postdural puncture headache, dilakukan epidural blood patch, dengan darah autologous, aman, dan efektif pada pasien dengan HIV seropositif. ${ }^{6}$ Anestesi regional tidak mempengaruhi ARV dan sistem imun. Pada seksio sesarea elektif, dipilih teknik anestesi regional karena dapat memberikan analgesia yang baik, menekan sekresi epinefrin dan norepinefrin, dimana keduanya dapat memperburuk aliran darah ke uterus dan ginjal. Keuntungan lain yang didapat adalah perfusi perifer yang lebih baik, aliran darah uteroplasenter meningkat, dan pengaruh obat anestesi pada bayi minimal. ${ }^{6}$

Pada pasien ini, pemantauan hemodinamik menggunakan monitor EKG, pulse oksimetri, dan tekanan darah. Selama operasi hemodinamik dengan tekanan darah sistolik $90-130 \mathrm{mmHg}$ dan diastolik 65-85 mmHg, nadi 84-96 x/menit. Selama operasi diberikan ephedrine untuk terapi hipotensi. Selama operasi berlangsung, kebutuhan cairan harus diperhatikan. Pada pasien dengan penyakit kronik (hipoalbuminemia), harus hati-hati dalam pemberian cairan karena dapat timbul edema paru. Pada kasus ini cairan yang digunakan adalah koloid dan kristaloid. Pemantauan kecukupan cairan dengan memantau urin output $0,5-1 \mathrm{cc} / \mathrm{kgBB} / \mathrm{jam}$. Selama operasi, produksi urin sebanyak $100 \mathrm{cc}$ dengan berat badan pasien $50 \mathrm{~kg}$. Perdarahan yang terjadi selama operasi $400 \mathrm{cc}$. Jumlah perdarahan ini tidak melebihi allowable blood loss, sehingga tidak perlu transfusi. Pada saat persalinan, kapasitansi vaskuler maternal berkurang oleh karena volume pada ruang intervilus (sekitar $500 \mathrm{~mL}$ ). Jadi, pada persalinan pervaginam atau bedah sesar volume darah tidak harus digantikan dalam rangka stabilitas hemodinamik. Hemokonsentrasi terjadi saat volume darah maternal menurun dari $94 \mathrm{cc} /$ $\mathrm{kgBB}$ pada kehamilan aterm sampai dengan 76 $\mathrm{cc} / \mathrm{kgBB}$ selama periode pascapartum sehingga harus diperhitungkan pemberian cairan pada ibu hamil. Pasien diobservasi di ruang operasi sampai blok motorik habis. Ketika didapatkan skor Bromage 0, pasien dapat dipindahkan ke ruangan. Hal ini untuk mengurangi paparan baik tempat maupun tenaga kesehatan. ${ }^{21}$

Anestesi umum dapat dilakukan tetapi harus memperhatikan interaksi obat dan penyakit multiorgan akibat infeksi HIV. Anestesi menurunkan imunitas seluler. ARV menghambat enzim sitokrom p450 sehingga dipilih etomidat, atrakurium, remifentanil dan desfluran yang tidak terpengaruh dengan sitokrom p450. Sedangkan tidak baku dipakai di awal kalimat opioid dan benzodiazepin dipengaruhi oleh sitokrom p450 sehingga penggunaannya harus lebih hati-hati. Suksinilkolin diberikan dengan hati- hati pada pasien dengan disfungsi ginjal dan kondisi adanya miopati. Keterlibatan patologi orofaringeal dan esofageal membuat pasien cenderung sulit intubasi, rentan regurgitasi dan aspirasi. ${ }^{6}$ Penggunaan anestesi umum harus memperhatikan adanya kelainan fungsi saraf (sentral maupun perifer).

Anestesi umum dapat menyebabkan depresi sementara pada fungsi sistem imun. Pemeriksaan jalan napas penting untuk memprediksi adanya kesulitan intubasi akibat pharyngeal lymphatic hypertrophy dan infeksi atau tumor di rongga mulut serta risiko migrasi kuman patogen di rongga mulut ke pulmoner. Interaksi obat anestesi dengan ARV juga perlu diperhatikan karena dapat menyebabkan pemanjangan efek dari obat 
tersebut. ${ }^{22}$ Keterlibatan sistim pernapasan dengan keadaan patologis orofaringeal dan esofageal membuat pasien HIV lebih rentan mengalami regurgitasi, kesulitan intubasi dan aspirasi. Infeksi paru opportunistik memperpanjang penggunaan ventilasi mekanis pasca operasi. ${ }^{23}$ Anestesi umum pada pasien HIV dapat menyebabkan imunosupresi 15 menit setelah induksi dan paling lambat menghilang setelah 11 hari setelah operasi. Kemampuan interaksi obat yang tidak dapat diprediksi seharusnya selalu diperhatikan ${ }^{23,24}$ Etomidat aman digunakan untuk induksi (tidak terjadi metabolisme sitokrom p450). Bagaimanapun, resiko insufisiensi ad- renal harus dipertimbangkan. Tidak ada kontraindikasi yang jelas terhadap penggunaan propofol atau sodium tiopenton. Desfluran secara teori bermanfaat untuk mengurangi metabolisme. Remifentanil adalah opioid terpilih, morfin secara umum aman. Dosis harus diperhatikan, berdasarkan respon pasien, dan dapat meningkat pada pasien dengan terapi NNRTIs, atau berkurang pada pasien yang menggunakan PIs. Secara umum, petidin harus dihindari. ${ }^{24}$

Standar keamanan dengan niversal Precaution harus dilakukan ketika berhadapan dengan darah, produk darah, cairan tubuh, dan jaringan dari semua pasien. Karena tidak baku dipakai di awal kalimat terdapat "window period" di antara infeksi HIV primer dengan serokonversi, diagnosis dapat terlambat ditegakkan. Transmisi penyakit lain seperti hepatitis B dan C harus dipertimbangkan. Penggunaan sarung tangan mencegah $98 \%$ kontak dengan darah pasien dan cairan tubuh. Masker dan pelindung mata mengurangi risiko paparan. Risiko transmisi HIV dari cedera tertusuk jarum sekitar $0,32 \%$. Setiap tenaga kesehatan dengan cedera tertusuk jarum harus mendapatkan segera terapi antiretroviral. Obat harus diberikan dalam jam pertama sejak paparan sehingga mengurangi laju serokonversi $80 \%$. Faktor yang menentukan risiko paparan tenaga kesehatan meliputi jumlah darah yang terkena, prosedur penggunaan jarum, kedalaman cidera tertusuk jarum, dan titer virus pasien yang terinfeksi HIV. ${ }^{25}$ Transmisi HIV di rumah sakit terhadap tindakan anestesi terjadi melalui: ${ }^{26}$ pasien kepada tim anestesi, pasien kepada pasien, tim anestesi kepada pasien.
Universal precaution sebagaimana didefinisikan oleh CDC (Centers for Disease Control and Prevention) merupakan rangkaian precaution yang dirancang untuk mencegah transmisi HIV terhadap tenaga kesehatan ketika sedang menjalankan pelayanan kesehatan. Universal Precaution meliputi kontak dengan darah, cairan tubuh termasuk darah, semen, sekret vagina, jaringan, cairan serebrospinal, pleura, peritoneum, pericardial, serta cairan amnion. Universal precaution tersebut meliputi: ${ }^{1}$

Cuci tangan: salah satu hal yang paling penting adalah cuci tangan sebelum dan sesudah berhadapan dengan pasien. Cuci tangan yang benar mengurangi risiko transmisi HIV dan agen infeksius lain. Menggunakan sarung tangan: sepasang sarung tangan digunakan dan dapat digandakan saat pembedahan untuk menghindari risiko cedera objek tajam. Kaca mata dan masker: mata dapat dilindungi dari kontak sekret dengan menggunakan goggle, masker dan topi melindungi kepala dan wajah dari paparan cairan tubuh. Alas kaki: kaki berisiko terkena serpihan dan abrasi yang mungkin terkontaminasi dengan cairan tubuh. Gaun: apabila tersedia, dapat digunakan gaun disposable, atau dapat digunakan apron plastik untuk melindungi dari paparan. Jarum dan benda tajam: manipulasi pada jarum termasuk menutup kembali dihindari. Jarum dan benda tajam langsung dimasukkan ke dalam kotak khusus benda tajam. Apabila sudah dua per tiga penuh maka box harus segera dibawa ke incinerator. Teknik bedah: risiko cedera tertusuk jarum paling besar pada prosedur bedah pelvis, hiatus diafragma atau toraks, dihindari penggunaan tangan untuk mengarahkan jarum.

Linen: merendam linen selama 30 menit dalam larutan bleach 1:100 (larutan hipoklorit) membunuh virus, proses ini dapat dilakukan dengan mencuci atau dengan autoklaf. Instrumen logam: instrumen dicuci dengan sabun dan air, kemudian direndam dalam larutan 2\% glutaraldehid selama 30 menit untuk membunuh virus, instrumen tajam dipindah ke kontainer lain dengan glutaraldehid baru dan direndam selama enam jam, instrumen yang lain dapat disterilkan dalam autoclav. Selang suction dan tabungnya direndam dalam larutan 2\% gluutaraldehid selama enam jam setelah dicuci dengan sabun dan 
air, dapat juga disterilkan dengan etilen oksida.

\section{Simpulan}

HIV (Human Immunodeficiency Virus) merupakan retrovirus bersifat limfotropik khas yang menginfeksi sel-sel dari sistem kekebalan tubuh, menghancurkan atau merusak sel darah putih spesifik yang disebut limfosit T-helper atau limfosit pembawa faktor T4 (CD4). Penyakit ini dapat menyebabkan kerusakan multiorgan, baik karena infeksi primer, infeksi sekunder maupun karena terapi ARV nya. Selain itu, terapi ARV juga dapat menyebabkan interaksi dengan obatobatan anestesi yang digunakan.

Penanganan pasien hamil dengan HIV melibatkan multidisiplin ilmu. Optimalisasi terapi antiretroviral dan suportif serta bedah sesar elektif dapat mengurangi angka kejadian transmisi vertikal. Penatalaksanaan anestesi sesuai kondisi pasien dengan memperhatikan anamnesis, pemeriksaan fisik, dan pemeriksaan penunjang yang diperlukan. Anestesi neuraksial aman diberikan pada sebagian besar pasien hamil dengan HIV positif. Tidak ada kontraindikasi general anestesi, neuroaksial, maupun anestesi regional pada pasien penderita HIV, namun perlu dievaluasi dengan baik preoperative baik dari anamnesis, pemeriksaan fisik, maupun hasil pemeriksaan penunjang untuk mengurangi angka mortalitas pasien HIV yang mendapatkan tindakan operasi dan mencegah penularan pada petugas kesehatan.

\section{Daftar Pustaka}

1. Parthasaraty S, Ravisankhar M. HIV and anaesthesia. Indian $\mathrm{J}$ Anaesth. 2007;51(2):91-9.

2. Brooks GF, Butel JS, Morse SA. S dan Lentivirus. Dalam: Mikrobiologi Kedokteran Jawetz, Melnick, \& Adelberg. Jakarta: EGC. 2007. 617-32.

3. Wiknjosastro H, Saifuddin A B, Rachimhadhi T. Penyakit Menular. Dalam: Wiknjosastro H, Saifuddin A B, Rachimhadhi T. eds.
Ilmu Kebidanan. Jakarta: Yayasan Bina Pustaka Sarwono Prawirohardjo d/a Bagian Kebidanan dan Kandungan Fakultas Kedokteran Universitas Indonesia. 2006. 556.

4. Depkes RI. Pedoman Nasional Terapi Antiretroviral, dengan Panduan Tatalaksana Klinis Infeksi HIV pada Orang Dewasa dan Remaja. Ed II. Departemen Kesehatan Republik Indonesia. 2009

5. Newell ML, Coovadia H, Cortina-Borja M, Rollins N, Gaillard P, Dabis F. Mortality of Infected and Uninfected Infants Born to HIV- Infected Mothers in Africa: A Pooled Analysis. Lancet. 2004. 364 (9441):1236-43.

6. Baluch A, Maass H, Rivera C, Gautam A, Kaye A, Frost EAM. Current Perioperative Management of The Patient with HIV. In: M.E.J. Anesthesia. 2009. 20(2): 167-77.

7. Prawirohardjo S. Infeksi Menular Seksual. Dalam: Ilmu Kebidanan. Edisi Ketiga. Jakarta: PT. Bina Pustaka Sarwono Prawirohardjo. 2010. 921-33.

8. Center Disease Control and Prevention. Mother-to-Child (Perinatal) HIV Transmission and Prevention. Diakses dari https://www.cdc.gov/hiv/grup/gender/ pregnantwomen/index.html 2012.

9. Kemenkes RI. 2014. Data Kasus HIV/AIDS di Indonesia Tahun 2014. Kementerian Kesehatan Republik Indonesia.

10. Ruth E, Eileen M, Susan P, Yvonne J. Perinatal transmission of major, minor, and multiple maternal human immunodeficiency virus type-1 variants in utero and intrapartum. Journal of Virology. 2007, 75(5):2194-203.

11. Ramakrishnan R, Mehta R. Characterization of HIV-1 envelope gp41 genetic diversity and functional domains following perinatal transmission. Journal of Retrovirology. 2006. $3: 42$. 
12. Depkes RI. Pedoman Nasional Terapi Antiretroviral, dengan Panduan Tatalaksana Klinis Infeksi HIV pada Orang Dewasa dan Remaja. Ed II. Departemen Kesehatan Republik Indonesia. 2009

13. Hines RL \& Marschall KE. Infectious Diseases In: Stoelting's Anesthesia and CoExisting Disease. Churchill Livingstone. 2008.

14. UNICEF.2013.PreventionofMother-to-Child Transmission (PMTCT) of HIV. UNICEF.

15. World Health Organization. Pelayanan Kesehatan Ibu di Fasilitas Kesehatan Dasar dan Rujukan. World Health Organization. 2013.

16. The American College of Obstetricians and Gynecologist. 2014. Routine Human Immunodeficiency Virus Screening. Diakses dari http://www.acog.org/About_ ACOG/ ACOG_Departments/HIV/Routine_HIV Screening_Resources.

17. Cunningham FG, Leveno KJ, Bloom SL, Hauth JC, Gilstrap LC, Wenstrom KD. 2005. Obstetri Williams. Jakarta: EGC.

18. Schulenburg E, Le Roux P. Antiretroviral therapy and anaesthesia. S Afr J Anaesthesiol Analg. 2008;14(2):31-38.

19. Evron S, Glezerman M, Harow E, Sadan O, Ezri T. Human Immunodeficiency Virus Anesthetic and Obstetric Considerations in:
Anesth \& Analg. 2004; 98: 503-511.

20. Chestnut DH. Cesarean Section in: Obstetric Anesthesia Principles and Practice. Elsevier Mosby. 2004.

21. Mandee S, Siriussawakul A, Suraseranivongse S, Khanwilai J, Nitigarun P. Time Duration to Safety Sitting in Parturient Receiving Spinal Anesthesia for Cesarean Section with 0,5\% Bupivacaine and Morphine. In: Asian Biomedicine. 2010; 4 (3): 485-89.

22. Ahmad MR \& Lami B. Seksio Sesarea pada Pasien HIV dalam: Anestesi Obstetri. Komisi Pendidikan SpAnKAO Kolegium Anestesiologi dan Terapi Intensif Indonesia. Bandung. 2013, 189-200.

23. Paull J. Epidural analgesia for labor. In: Birnbach DJ et al. (ed); Textbook of Obstetric Anaesthesia Philadelphia: Churchill Livingstone, 2000, 145-54.

24. Birnbach DJ, Hernandez M. Neuraxial analgesia for labor in spinal and epidural anaesthesia, Wong CA, (ed). New York: Mc Graw-Hill, 2007; 257-74.

25. Kuczkowski KM. Anesthetic Considerations for the HIV-Infected Pregnant Patient. In: Yonsei Medical Journal. 2004; 45 (1): 1-6.

26. Datta S, Kodali BS, Segal S. Infectious Diseases in: Obstetric Anesthesia Handbook 5th edition. Springer. 2010. 289-291. 